cemoti $\begin{aligned} & \text { Cahiers d'études sur la Méditerranée } \\ & \text { orientale et le monde turco-iranien }\end{aligned}$

$20 \mid 1995$

Médias d'Iran et d'Asie centrale

\title{
Women's issues in the recent Afghan revolutionary movements
}

Helena MALIKYAR

\section{(2) OpenEdition}

Édition électronique

URL : http://journals.openedition.org/cemoti/192

DOI : $10.4000 /$ cemoti.192

ISSN : $1777-5396$

Éditeur

AFEMOTI

\section{Édition imprimée}

Date de publication : 1 juin 1995

Pagination :

315-325

ISSN : 0764-9878

\section{Référence électronique}

Helena MALIKYAR, "Women's issues in the recent Afghan revolutionary movements ", Cahiers d'études sur la Méditerranée orientale et le monde turco-iranien [En ligne], 20 | 1995, mis en ligne le 30 mars 2004, consulté le 08 septembre 2020. URL : http://journals.openedition.org/cemoti/192 ; DOI : https://doi.org/10.4000/cemoti.192

Ce document a été généré automatiquement le 8 septembre 2020.

Tous droits réservés 


\title{
Women's issues in the recent Afghan revolutionary movements
}

\author{
Helena MALIKYAR
}

\section{RÉSUMÉS}

The progress and regress of women's rights in the course of Afghanistan's modern history has had a direct correlation with the dynamics of power politics in that country. From the modernization efforts of King Aman Allah and his reformist wazir, Mahmoud Tarzi in the 1920's, to the modernist and letist ideologues of the 1960's, women's legal status and rights to acquire an education and participate in the national economy constituted an important part of Afghan political rhetoric. With the Soviet invasion of 1979 and the emergence of Islamist resistance parties in the 1980's, women's issues became, more than ever, a dominant feature of political demagoguery. During that time, as in the short period in 1929 when Habib Allah Kalakani led a reactionary revolution, the slogans and religious decrees were issued against women's education and female participation in public life. In short, whether in favor or against women's rights, various ideological and revolutionary movements in Afghanistan have used the issue as a focal point in their political discourse. 